\title{
BRYTYJSKIE CZASOPISMA NAUKOWE Z OBSZARU STOSUNKÓW MIĘDZYNARODOWYCH - PRZEGLĄD 2016 ROKU
}

Celem niniejszego artykułu przeglądowego jest zaprezentowanie przeglądu prac z brytyjskich czasopism naukowych podejmujących tematykę stosunków międzynarodowych i opublikowanych w 2016 r. Analizie poddane zostały zatem artykuły z następujących pism: „The British Journal of Politics and International Relations”, „Politics”, „International Relations” oraz „Political Studies”. Subiektywny wybór najbardziej interesujących publikacji został zatem dokonany spośród ponad 100 artykułów opublikowanych w 16 wydaniach tych czterech czasopism.

Tematyka publikacji w minionym roku była bardzo zróżnicowana. Pomimo faktu, iż głównym wydarzeniem w życiu publicznym Wielkiej Brytanii było w 2016 r. referendum dotyczące opuszczenia przez to państwo struktur Unii Europejskiej, to nie odzwierciedlała tego tematyka publikowanych artykułów w analizowanych czasopismach. Tak jak w roku 2015 tematyka potencjalnego Brexitu była wyraźnie zauważalna w rozważaniach naukowców, tak w roku 2016 artykuły nie odnosiły się bezpośrednio do kwestii referendum. Nawiązując natomiast do dyskusji o miejscu Wielkiej Brytanii w Unii Europejskiej i konsekwencjach z tym związanych, częściej publikowane były artykuły dotyczące problemów polityki migracyjnej, czy terroryzmu. Pośrednio jednak to te wyzwania stanowiły także trzon debaty referendalnej.

Bardzo popularną tematyką $\mathrm{w}$ analizowanych czasopismach $\mathrm{w}$ minionym roku była również problematyka bliskowschodnia. Co jednak zaskakujące, niewiele artykułów dotyczyło jedynie kwestii tzw. Państwa Islamskiego w Iraku i Syrii (ang. Islamic State in Iraq and Syria - ISIS). To również istotna zmiana w stosunku do 2015 r., gdzie działalność ISIS była popularnym tematem artykułów naukowych w brytyjskich czasopismach. W roku 2016 większym zainteresowaniem cieszyły się analizy sytuacji w konkretnych państwach, takich jak chociażby Jordania czy Turcja.

Publikacje z roku 2016 były zdecydowanie bardziej zróżnicowane niż w roku poprzednim. Poza tematyką migracji, terroryzmu i Bliskiego Wschodu znaleźć można było również artykuły dotyczące Chińskiej Republiki Ludowej. Publikacje dotyczące tego państwa wskazywały zarówno na jego obecną pozycję w ładzie międzynarodowych, jak i na przyszłe, potencjalne aspiracje. Odnosiły się one także do relacji ChRL ze Stanami Zjednoczonymi i ich rywalizacji międzynarodowej.

Inną interesującą tematyką były także artykuły poświęcone problemom i wyzwaniom, przed którymi stoi obecnie liberalna demokracja w państwach świata zachodniego. Publikacje te dotyczyły całego spektrum zagrożeń, które wpływają na destabilizację współczesnych demokracji, ale i propozycji rozwiązań, które mogłyby temu 
zaradzić. Nie pomijano także roli ludzi młodych, których zaangażowanie (czasem brak zaangażowania) również stanowi istotne wyzwanie, które stoi przed rządzącymi, jeśli Ci chcą utrzymać znany nam współcześnie model demokracji liberalnej.

Pomimo faktu, iż w roku 2016 artykułów dotyczących stricte referendum dotyczącego opuszczenia UE przez Wielką Brytanię było bardzo mało, to część publikacji odnosiła się do głównych wątków kampanii referendalnej, a mianowicie kwestii polityki migracyjnej oraz przyjętego systemu ekonomicznego w ramach UE (Gifford, 2016; Tonkiss, 2016; Balch, Balabanova, 2016). Co jednak interesujące z punktu widzenia polskiego czytelnika w opublikowanych pracach nie poruszano kwestii migracji Polaków do Wielkiej Brytanii. W czasopiśmie „Politics” Alex Balch i Ekaterina Balabanowa podjęli natomiast problematykę migracji Bułgarów oraz Rumunów na wyspy brytyjskie oraz wpływu, jaki miało to na tamtejszą scenę polityczną oraz odczucia społeczne. Autorzy zauważyli już na początku, że dyskusja na temat skutków otwarcia granic dla migrantów z dwóch badanych państw pojawiała się w dyskursie publicznym jeszcze przed dojściem do władzy Partii Konserwatywnej. Przypominają oni, iż jeszcze w roku 2007 lider Partii Pracy Gordon Brown w swoim przemówieniu stwierdził, iż dostrzega potrzebę zapewnienia miejsc pracy dla Brytyjczyków, którzy czują się wypchnięci z rynku pracy. Natomiast jak zauważają także kolejny lider tej partii - Ed Miliband przepraszał w roku 2012 za błędy popełnione przez swoich poprzedników w kontekście polityki migracyjnej i otwarcia granic dla obywateli Bułgarii i Rumunii (Balch, Balabanowa, 2016: 22). Główną część artykułu stanowią natomiast wyniki analiz mediów brytyjskich i podejmowanych tematów w stosunku do omawianego tematu w roku 2006 oraz 2013. Najczęściej odnosiły się one do konieczności wprowadzenia kontroli napływu imigrantów z Bułgarii oraz Rumunii w imię wewnętrznej sprawiedliwości społecznej w Wielkiej Brytanii. Warto jednak zauważyć, iż taka argumentacja w roku 2006 dotyczyła 65\% materiałów, natomiast już w 2013 r. - 50\%. Co interesujące, w roku 2013 częściej pojawiała się natomiast argumentacja bezpieczeństwa publicznego $(10 \%-2006,21 \%$ - 2013), jako głównego powodu konieczności wprowadzenia kontroli przyjazdu imigrantów z Bułgarii i Rumunii (Balch, Balabanova, 2016: 25).

Z punktu widzenia brytyjskiej kampanii referendalnej interesujący jest również artykuł Chrisa Gifforda, który analizuje relacje Wielkiej Brytanii i Unii Europejskiej w odniesieniu do systemów ekonomicznych, na których oparte są te podmioty. Autor przytacza argumenty, które mają udowodnić, iż brytyjska gospodarka korzysta z rozwiązań neoliberalnych i kolejne reformy idące w tym kierunku służą społeczeństwu brytyjskiemu, podczas gdy system gospodarczy Unii Europejskiej zbudowany jest w taki sposób, aby wspierać niemiecki model gospodarczy (Gifford, 2016: 782). Jego zdaniem w referendum, które miało miejsce, to fakt bycia zwolennikiem, bądź przeciwnikiem Unii Europejskiej i procesów integracyjnych było decydującym. Kluczowym był stosunek do wizji rozwoju ekonomicznego, w przypadku którego Unia Europejska była kojarzona z przeregulowaniem rynku i hamowaniem potencjału wzrostu Wielkiej Brytanii (Gifford, 2016: 785). Jak jednak konstatuje w swoim artykule, to postawa liderów politycznych zadecydowała o ostatecznym wyniku głosowania. Bowiem to oni podsycali w ostatnich latach nastroje eurosceptyczne deklarując odcięcie się od problemu kryzysu w strefie euro. Decydujące było także wskazywanie przez 
nich na konieczność ochrony interesu narodowego w obliczu potencjalnej ściślejszej integracji państw posiadających wspólną walutę (Gifford, 2016: 788).

Równie popularne jak kwestie migracji w analizowanych publikacjach były artykuły związane z problematyką terroryzmu. Tematyka ta poruszana była $\mathrm{z}$ różnorodnych perspektyw. James A. Malcom w artykule dotyczącym zabezpieczenia brytyjskich portów morskich wobec zagrożenia terrorystycznego opublikowanym na łamach „The British Journal of Politics and International Relations" prezentuje on kolejne etapy, które podejmowane były przez administrację portów i rząd brytyjski zaczynając od roku 2004'. W szczególności kładzie on nacisk na analizę rozwiązań przyjętych przez Międzynarodowy Kodeks Ochrony Statku i Obiektu Portowego (ang. International Ship and Port Faciliy Security Code - ISPS) (Malcolm, 2016).

Wykładowców i osoby prowadzące zajęcia ze studentami zainteresować powinien natomiast artykuł Aarona Ettingera, który podjął się rozważań na temat tego jak uczyć studentów o wojnach po ataku z 11 września 2001 r., jeśli są oni za młodzi, aby pamiętać jak wyglądał świat i konflikty zbrojne przed tym wydarzeniem. Zwraca on uwage, iż dla wielu obecnych studentów atak na World Trade Center jest jednym z wielu wydarzeń historycznych i nie stanowi punktu przełomowego, do którego odnoszą się swoimi wspomnieniami (Ettinger, 2016: 200). Dlatego też jego zdaniem więcej uwagi należy przyłożyć do wytłumaczenia studentom różnic pomiędzy obecnymi konfliktami zbrojnymi a tymi sprzed tzw. wojny z terroryzmem. Jak przyznaje, podobny problem już w perspektywie kilku lat dotyczyć będzie także nauczania o modelu gospodarczym świata zachodniego w odniesieniu do kryzysu finansowego z lat 2007-2009 (Ettinger, 2016: 207).

Czytelnika zainteresować mogą również dwa artykuły odnoszące się do problematyki zakazu tortur w prawie międzynarodowym. Opublikowane na łamach „International Relations” oraz „Political Studies” artykuły zapewne w niezamierzony sposób prezentują odmienne punkty widzenia na tę kwestię. Mathias Thaler na łamach drugiego z wymienionych czasopism stara się krytycznie przeanalizować najbardziej istotne głosy w dyskusji naukowej na temat zasadności zakazu tortur oraz przeciwnych twierdzeń. Ostatecznie argumentuje, iż to pragmatyzm oparty na praktykach liberalnych demokracji powinien wymuszać tworzenie konstytutywnych reguł zakazujących stosowania tortur, odcinając się jednocześnie od transcendentnych wartości, które ograniczałyby działanie polityczne (Thaler, 2016: 772). Jamal Barnes podkreśla natomiast niedookreślenie samego terminu tortur. Jego zdaniem bardzo niewyraźna jest różnica pomiędzy zadawaniem bólu, które jest tortura, a takim które nim nie jest. W swojej pracy opiera się on na praktykach stosowanych w bazie Guantanamo. W artykule odnaleźć można listę praktyk, które miały miejsce na kolejnych etapach przesłuchań oraz nazwiska osób, które na te praktyki wyraziły zgodę. Zaznaczony jest również fakt niedopuszczenia do stosowania niektórych z proponowanych zachowań wobec podejrzanych (Barnes, 2016: 111). Co więcej, autor zauważa iż stosunek społeczeństwa do stosowania tortur jest zróżnicowany, co pokazują badania amerykańskiej opinii publicznej, która w 55\% sprzeciwiała się takim praktykom, ale aż 40\% wyrażała

111 marca 2004 r. miał miejsce zamach terrorystyczny w Madrycie, który był pierwszym od czasów ataku na World Trade Center tak poważnym atakiem terrorystycznym przeprowadzonym przez Al-Kaidę na terenie Europy. 
przychylność wobec nich (Barnes, 2016: 114). Jak jednak konstatuje, tortury stanowią we współczesnych stosunkach międzynarodowych swoisty temat tabu. Jego zdaniem nawet chęć zmienienia tego stanu rzeczy przez administrację Stanów Zjednoczonych nie przyniosło skutku. Stało się tak, gdyż jak twierdzi niemożliwe jest jednostronne zredefiniowanie tak ważkiego terminu jak tortury poprzez jednostronne działanie, nawet w przypadku potęgi, jaką są USA (Barnes, 2016: 115).

Sporo uwagi w brytyjskich czasopismach poświęca się także problematyce bliskowschodniej. Interesująco prezentuje się artykuł omawiający kwestie stosunku przedstawicieli Al-Kaidy wobec stosowania prawa szariatu na terytorium państw muzułmańskich. Jest to istotny temat z perspektywy przemian tzw. Arabskiej Wiosny, podczas których na popularności zyskiwała idea przyjęcia przez państwa Afryki Północnej i Bliskiego Wschodu tzw. modelu tureckiego. Takie podejście wywoływało oburzenie ze strony salafitów (radykalnych muzułmanów) związanych z Al-Kaidą, którzy nie chcieli zgodzić się na hybrydy łączące nowoczesne państwo z istotną rolą religii (Holbrook, 2016: 478). Co interesujące, autor tego artykułu opisuje również spór pomiędzy przedstawicielami Al-Kaidy oraz ISIS o to, kto jest bardziej wierny zasadom szariatu. Stało się tak, ponieważ nawet z perspektywy liderów tej pierwszej organizacji ISIS jest zbyt radykalne w stosowaniu przemocy, która ich zdaniem jest kontrproduktywna, w szczególności wymierzana wobec innych muzułmanów (Holbrook, 2016: 480).

Nawiązując do tureckiego systemu politycznego, warto zwrócić uwagę na artykuł Zeynep Sahin-Mencutek, która opisuje problematykę partycypacji kobiet w tureckim życiu politycznych na przykładzie działalności Partii Pokoju i Demokracji (tur. Barlş ve Demokrasi Partisi - BDP). Zwraca ona uwagę, iż większość badań dowodzi większej aktywności kobiet w partiach lewicowych, niż w partiach prawicowych. Przez to jej zdaniem czasem mylne jest postrzeganie partii etno-nacjonalistycznych jako partii prawicowych, ponieważ poza tematyką separatystyczną w większości reprezentują one program lewicowy, co potwierdza również wysoka aktywność kobiet (SahinMencutek, 2016: 472). W swojej pracy wskazuje, iż w latach 2002-2011liczba kobiet w tureckim parlamencie systematycznie wzrastała, ale i tak w przypadku dwóch największych partii politycznych liczba kobiet parlamentarzystek nie przekroczyła $15 \%$. Natomiast w odniesieniu do partii BDP w roku 2011 wynik wyniósł ponad 35\%. Stało się tak jej zdaniem nie tylko poprzez prezentowany program, ale również dzięki przyjętym rozwiązaniom organizacyjnym, gdzie w przypadku remisu w głosowania nad objęciem stanowiska w strukturach wewnętrznych, stanowisko to obejmuje kobieta. Także składka członkowska dla kobiet została w tej partii obniżona oraz wprowadzono $40 \%$ kwoty zarówno do organów wewnętrznych organizacji, jak i na listach wyborczych $^{2}$ (Sahin-Mencutek, 2016: 475-476).

W kontekście artykułu Stacey Gutkowski interesująca jest natomiast interdyscyplinarność. Z jednej strony porusza ona rolę, jaką odgrywa Islam w Jordanii. Z drugiej natomiast wskazuje na miejsce jakie zajmuje on w dyplomacji publicznej tego państwa. Jej zdaniem Jordania po atakach na World Trade Center postanowiła za pośred-

${ }^{2}$ Aktualnie $\mathrm{w}$ tureckim parlamencie Kurdów reprezentuje Ludowa Partia Demokratyczna (Halkların Demokratik Partisi - HDP), która od początku współpracowała z BDP, a ostatecznie to ona stała się sukcesorką BDP na arenie krajowej. 
nictwem retoryki swoich liderów prezentować się jako przedstawicielka umiarkowanego Islamu. Taka polityka nazywana jest nawet filarem, na którym budowany miał być branding narodowy tego państwa. Autor zwraca jednak uwagę, że uwzględniając traktowanie opozycji w Jordanii oraz ograniczoną wolność słowa strategia ta okazuje się nieskuteczna (Gutkowski, 2016: 209-210).

Ostatnim obszarem badawczym cieszącym się popularnością w 2016 r. w brytyjskich czasopismach była problematyka polityki zagranicznej Chińskiej Republiki Ludowej. W tym kontekście ciekawym jest artykuł w „International Relations” dotyczący stosunku tego państwa do polityki R2P (responsibility to protect). Z jednej strony Chińska Republika Ludowa poparła Rezolucję nr 1674 Rady Bezpieczeństwa ONZ dotyczącą polityki R2P, z drugiej natomiast zachowuje wobec niej dużą dozę wstrzemięźliwości. Zgodnie bowiem z założeniami ich polityki międzynarodowej jakakolwiek aktywność na tym polu może być podjęta jedynie w wypadku ludobójstwa, zbrodni wojennych, czystek etnicznych, bądź zbrodni przeciwko ludzkości (Kozyrev, 2016: 333). Sceptycyzm wobec tej omawianej polityki wiąże się również z tradycją Chin do nieangażowania się militarnego w innych państwach. Uwidocznił się on w szczególności w trakcie wydarzeń w Libii oraz Syrii w okresie Arabskiej Wiosny. Z punktu widzenia ChRL polityka R2P stosowana była tylko w odniesieniu do wybranych państw, gdy państwo przeprowadzające interwencję oczekiwało wymiernych korzyści (Kozyrev, 2016: 334).

Czytelników zainteresować powinien także artykuł opublikowany na łamach „The British Journal of Politics and International Relations" przez Jinghan Zenga. Stanowi on analizę treści 141 artykułów opublikowanych przez chińskich naukowców, a dotyczących problematyki nowych mocarstw w stosunkach międzynarodowych. Problematyka ta jest w szczególności istotna z punktu widzenia propozycji, jaką złożył Xi Jinping w czasie swojej wizyty w Waszyngtonie w 2012 r. Zaproponował on amerykańskiej administracji ustanowienie nowego rodzaju relacji supermocarstw w XXI wieku. Zdaniem autora artykułu taka propozycja była związana z chęcią ucieczki z tzw. próby Tukidydesa. Opisuje ona nieuchronność wojny w przypadku, gdy mocarstwo dominujące dostrzega dynamiczny wzrost innego mocarstwa i obawia się o utratę swojej pozycji (Zeng, 2016: 430). Zeng uważa jednak, że USA są bardzo wstrzemięźliwe wobec ustanowienia takich specjalnych relacji, ponieważ uznałyby tym samym równorzędną pozycję ChRL na arenie międzynarodowej (Zeng, 2016: 431).

Uwzględniając współczesne przemiany i problemy, z którymi mierzą się demokracje w Europie interesująco w 2016 r. jawiły się także artykuły dotyczące kwestii partycypacji społecznej w państwach Unii Europejskiej. W tym kontekście zainteresować mogą w szczególności dwa artykuły. Pierwszy z nich przygotowany przez Yvette Peters traktuje o korelacji narzędzi demokracji bezpośredniej z frekwencjami wyborczymi. W swojej pracy prezentuje ona poszczególne z narzędzi demokracji bezpośredniej stosowane w różnych państwach świata. Dzieli je także na spójne grupy, aby przyjrzeć się ich korelacji z późniejszymi frekwencjami wyborczymi. Ostatecznie dochodzi do wniosku, że niektóre z instrumentów demokracji bezpośredniej faktycznie mogą minimalnie poprawić uczestnictwo w wyborach krajowych, jednak część z nich może również drastycznie obniżyć tę frekwencję. Staje się tak dlatego, że społeczeństwa traktują 
te narzędzia niejako zamiennie z udziałem w głosowaniu, choć co prawda dotyczy to jedynie dojrzałych demokracji zachodnich (Peters, 2016: 603).

Ostatni z omawianych artykułów dotyczy natomiast badań przeprowadzonych w tzw. państwach starej Unii Europejskiej ${ }^{3}$ na grupie młodych obywateli w wieku od 15 do 24 lat. W badaniach uwzględniano między innymi uczestnictwo $\mathrm{w}$ wyborach (w grupie uprawnionej), podpisywanie petycji, uczestnictwo w bojkotach konsumenckich lub w demonstracjach (Sloam, 2016: 524). Opublikowane wyniki wskazują, iż największy stopień partycypacji ludzi młodych w życiu publicznym osiagają takie państwa jak Szwecja, Dania oraz Francja. Najniższy poziom zanotowano natomiast w Portugalii, Wielkiej Brytanii oraz Irlandii. Warto w tym miejscu podkreślić, iż jedynie 3\% badanych Brytyjczyków uczestniczyło w jakiejkolwiek demonstracji, a $36,5 \%$ z posiadających uprawnienia, brało udział w krajowych wyborach. Dla porównania największy odsetek młodych ludzi biorących udział w demonstracjach odnotowano w Luksemburgu - 35,6\%, a najwyższy poziom frekwencji wśród badanej grupy uzyskano w Szwecji - 79,2\% (Sloam, 2016: 526). Sumarycznie badani europejczycy korzystali ze swoich praw wyborczych w niespełna $60 \%$, co i tak jest zdecydowanie gorszym wynikiem od całkowitej frekwencji w badanych państwach. W odniesieniu do całych społeczeństw, młodzi europejczycy częściej uczestniczą jedynie w demonstracjach polityczno-społecznych, które w minionych latach przyjmowały również formy protestów ponadnarodowych, jak choćby w przypadku dyskusji na temat $\mathrm{ACTA}^{4}$, lub umów handlowych ze Stanami Zjednoczonymi (TTIP) czy Kanadą (CETA) (Sloam, 2016: 530).

Podsumowując należy zauważyć, iż publikowane w 2016 r. artykuły w brytyjskich czasopismach z obszaru stosunków międzynarodowych obejmowały szeroki wachlarz zagadnień tematycznych. W procesie subiektywnego wyboru najbardziej interesujących, spora część nie została jednak zaprezentowana. Zwraca natomiast uwagę fakt, iż podejmowana tematyka w mniejszym stopniu niż rok wcześniej skoncentrowana była wokół problemów i wyzwań brytyjskich, co tym bardziej dziwi wobec odbywającego się w 2016 r. referendum w Wielkiej Brytanii. Wciąż dostrzegane są natomiast zagadnienia związane z Bliskim Wschodem, terroryzmem, a także ChRL.

\section{Bibliografia}

Balch A., Balbanova E. (2016), Ethics, Politics and Migration Public Debates on the Free Movement of Romanians and Bulgarians in the UK, 2006-2013, „Politics”, Vol. 36/1.

Barnes J. (2016), The 'war on terror' and the battle for the definition of torture, „International Relations", Vol. 30/1.

Ettinger A. (2016), Teaching the Post-September 11 Wars to the Post-September 11 Generation, „Politics”, Vol. 36/2.

Gifford C. (2016), The United Kingdom's Eurosceptic political economy, „The British Journal of Politics and International Relations", Vol. 18/4.

315 państw członkowskich Unii Europejskiej sprzed rozszerzenia w $2004 \mathrm{r}$.

${ }^{4}$ ACTA - umowa handlowa dotycząca zwalczania obrotu towarami podrabianymi. Główny temat debaty wokół niej stanowiła ochrona własności intelektualnej zasobów internetowych, jednak protesty w dużej mierze dotyczyły obawy przed utratą anonimowości użytkowników Internetu. 
Gutkowski S. (2016), We are the very model of a moderate Muslim state: The Amman Messages and Jordan's foreign policy, „International Relations”, Vol. 30/2.

Holbrook D. (2016), Al.-Qaeda's grievances in context: reconciling sharia and society, „International Relations", Vol. 30/4.

Kozyrev V. (2016), Harmonizing 'Responsibility to Protect': China's vision of a post-soreveign world, „International Relations”, Vol. 30/3.

Malcolm J. A. (2016), Responding to international terrorism: The securitization of the United Kingdom's ports, „The British Journal of Politics and International Relations”, Vol. 18/2.

Peters Y. (2016), Zero-Sum democracy? The effects of Direct Democracy on Representative Participation, „Political Studies”, Vol. 64/3.

Sahin-Mencutek Z. (2016), Strong in the Movement, Strong in the Party: Women's Representation in the Kurdish Party of Turkey, „Political Studies”, Vol. 64/2.

Sloam J. (2016), Diversity and voice: The political participation of young people in the European Union, „The British Journal of Politics and International Relations”, Vol. 18/3.

Thaler M. (2016), A Pragmatist Defence of the Ban on Torture: From Moral Aboslutes to Constitutive Rules of Reasoning, „Political Studies”, Vol. 64/3.

Tonkiss K. (2016), Experiencing transnationalism at home: Open borders and the everyday narratives of non-migrants, „Politics”, Vol. 36/6.

Zeng J. (2016), Constructing a ,new type of great power relations": the state debate in China (19982014), „The British Journal of Politics and International Relations”, Vol. 18/2.

\title{
STRESZCZENIE
}

Artykuł stanowi przegląd artykułów opublikowanych w 2016 r. na łamach brytyjskich czasopism naukowych z obszaru stosunków międzynarodowych. Dokonano wyboru tekstów z 16 wydań czasopism: „International Relations”, „The British Journal of Politics and International Relations”, „Politics” oraz „Political Studies”. Prezentowane artykuły zostały przeanalizowane $\mathrm{w}$ ramach grup tematycznych takich jak: terroryzm, kwestie bliskowschodnie, polityka migracyjna Wielkiej Brytanii oraz polityka chińska.

Słowa kluczowe: przegląd czasopism, terroryzm, Wielka Brytania, Bliski Wschód, Chiny

\section{BRITISH SCIENTIFIC JOURNALS IN THE AREA OF INTERNATIONAL RELATIONS - 2016 OVERVIEW}

\begin{abstract}
The review constitutes a review of articles published in 2015 on the pages of British academic journals dealing with international relations. Texts from sixteen issues of: „International Relations”, „The British Journal of Politics and International Relations”, „Politics” and „Political Studies" have been selected. The presented articles have been analyzed in context of thematic groups such as: terrorism, Middle East issues, UK migration policy, and Chinese policy.
\end{abstract}

Keywords: journals review, terrorism, United Kingdom, Middle East, China 
